\title{
As lacunas dos quadrinhos
}

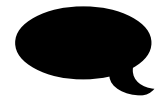

Roberto Elísio dos Santos

Doutor em Ciências da Comunicação

Observatório de Histórias em Quadrinhos da ECA-USP

A autora do livro - que nasceu na Holanda, lecionou no Canadá e, agora, é professora da universidade Massey, da Nova Zelândia - teve como o objetivo principal de sua obra apresentar aos leitores estadunidenses uma análise dos conceitos e das teorias formuladas por pesquisadores de quadrinhos europeus, como Roland Barthes e Thierry Groensteen, entre outros. A edição brasileira contou com a revisão técnica do professor Waldomiro Vergueiro.

O lançamento, ocorrido durante as 5as Jornadas Internacionais de Histórias em Quadrinhos da ECA-USP, realizadas de 22 a 24 de agosto de 2018 pelo Observatório de Histórias em Quadrinhos da ECA-USP, contou com a presença da própria autora. Em sua obra, ela afirma que, ao tratar da história dos quadrinhos ou analisar o seu conteúdo de um ponto de vista social, cultural ou narrativo, "chegase, inevitavelmente, à discussão de suas características formais" (p. 15).

Nessa perspectiva, a pesquisadora pondera que:

As condições materiais desse suporte, naturalmente, solicitam considerações sobre os elementos formais: a localização de quadros (ou vinhetas) e sarjetas, o tamanho e a forma dos títulos e recordatórios, e os ícones e símbolos usados na sua representação. (...)

Os vários elementos dos quadrinhos reúnem-se em sequências e narrativas ao trabalharem unidos como um sistema. (p.15)
A grande contribuição de Postema ao estudo das histórias em quadrinhos é enfatizar um elemento constitutivo da linguagem e da narrativa dos quadrinhos, as lacunas, "uma vez que a linguagem dos quadrinhos se apoia na força de suas ausências, nos seus gaps ou lacunas" ( $p$. 16). Esses lapsos são responsáveis para o sentido dado pelo leitor ao conteúdo das histórias. $\mathrm{Na}$ visão da professora:

Ao focar na lacuna, abre-se uma nova maneira de se conceituar como os quadrinhos funcionam. Em sua abstração, as imagens individuais dos quadrinhos deixam lacunas, ausências tanto no detalhe quanto na especificidade. A prática de circundar as imagens por molduras ou outro tipo de contorno para separar e definir as imagens começa a preencher essas lacunas ao tornálas mais evidentes. (...) As sarjetas são, literalmente, as lacunas da página, mas elas também marcam as lacunas presentes no nível seguinte do sistema. (...)

Precisamente, as lacunas - os lapsos de tempo entre os diferentes momentos da sequência - são o que produz a continuidade da sequência como se dois quadros (ou vinhetas) funcionassem para inferir o que acontece entre eles. (p. 16)

No primeiro capítulo, Postema trata da significação dentro dos quadros (requadros). De acordo com a autora:

As imagens dos quadrinhos geram um significado ao estabelecer um código de economia em que certos detalhes são deixados de lado para que outros se tornem

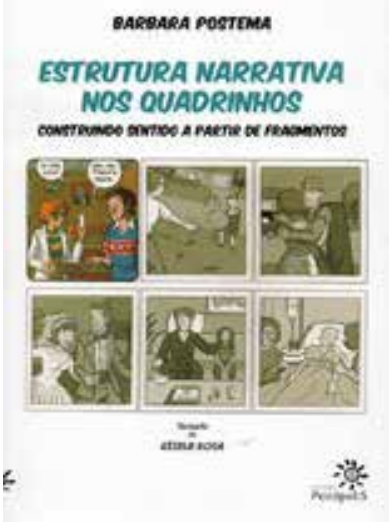

POSTEMA, Barbara. Estrutura narrativa nos quadrinhos: construindo sentidos a partir de fragmentos. São Paulo: Peirópolis, 2018 
mais importantes. (...) O plano representativo é fragmentado, deixando de fora todo tipo de detalhe. (...) A própria ausência de detalhe nos quadrinhos cria as condições pelas quais muitos signos que estão presentes trazem significado (p. 29).

Utilizando os conceitos formulados por Roland Barthes (langue - língua - e parole - fala), Postema aborda o sistema de signos que é formado. Para ela, "para compreender o sentido dos quadrinhos, se faz necessário pensar nas imagens que os constituem como coleções de signos visuais" (p. 30).

O layout das molduras e das sarjetas é o foco do segundo capítulo, que são os "elementos formais, estruturais, que amarram as imagens em sequências e criam as condições pelas quais as imagens dos quadrinhos trazem significado além do conteúdo de cada imagem individual". A autora procura preencher "a lacuna entre a imagem e a sequência, assim como a sua temática - quadros, molduras, layout" (p. 57). Ela estuda imagens que ocupam sozinhas uma ou duas páginas, a disposição de duas ou três vinhetas em uma página, etc., a partir do layout escolhido pelo artista.

Já o terceiro capítulo evidencia a sequência, que "é a maneira pela qual os quadrinhos criam a ação e, em última instância, a narrativa. As sequências podem ser longas ou curtas, e as narrativas podem ser criadas a partir de uma única sequência” (p. 87). Uma distinção importante feita pela professora Postema, respaldada pela teoria desenvolvida por Groensteen, diz respeito à sequência e à série. "Em alguns casos,o grupo de quadros sequenciais significa não uma sequência, mas uma série" (p. 104), embora a série seja menos evidente do que uma sequência, "uma vez que os quadros individuais que criam uma série não aparecem, necessariamente, um próximo ao outro".

A relação entre imagem e texto é esmiuçada no quarto capítulo. Inicialmente,
Postema aponta os limites entre as histórias em quadrinhos e a literatura, ressaltando que, embora compartilhem o mesmo suporte e ambas sejam narrativas, "as formas artísticas da literatura e dos quadrinhos são muito diferentes”. Ela destaca que, "enquanto no texto literário o verbal é a sua principal (ou única) força, com a qual se cria a representação, nos quadrinhos é o pictórico que impulsiona e cria a história e a obra”. A autora afirma, ainda, que o texto nos quadrinhos tem como função "preencher as lacunas deixadas pelas imagens, pelo layout, e pelas sequências". E acrescenta que a "inclusão do texto simultaneamente apresenta outra lacuna: o hiato entre a representação verbal e visual" (p. 115).

Finalmente, o quinto capítulo aborda o processo de narração. Citando Wolfgang Iser, Postema defende que a "lacuna é central para o processo de narração" (p. 146), principalmente em se tratando de histórias em quadrinhos. São as lacunas que mantêm o leitor envolvido, o qual faz a inferência do que está acontecendo e do que virá a acontecer."Em outras palavras, os leitores utilizam seu conhecimento de ações, de causalidade para preencher temporariamente, de forma hermenêutica, em que é necessário adaptálas como informações novas que se tornam disponíveis na narrativa". (p. 146)

O livro termina com dois apêndices um sobre a terminologia dos quadrinhos $\mathrm{e}$ o segundo a propósito de um panorama de gêneros e suas fases nos Estados Unidos, na Europa e no Japão - e um índice remissivo. 